Сумський державний педагогічний університет імені А. С. Макаренка anna_podosinnikova@ukr.net

Ковтун Тетяна Вікторівна, студентка,

факультет іноземної та слов'янської філології, Сумський державний педагогічний університет імені А. С. Макаренка tanyakovtun25@gmail.com

\title{
ФОРМУВАННЯ АНГЛОМОВНОЇ ЛЕКСИЧНӦ̈ КОМПЕТЕНТНОСТІ НА МАТЕРІАЛІ ІДІОМ В УЧНІВ 9 КЛАСУ ЗАКЛАДІВ ЗАГАЛЬНОЇ СЕРЕДНЬОЇ ОСВІТИ
}

У статті презентовано теоретичне обгрунтування та технологія формування англомовної лексичної компетентності на матеріалі ідіом в учнів 9 класу закладів загальної середньої освіти. Окреслено релевантні психолого-вікові особливості підлітків, розглянуто поняття лексичної компетентності, зміст лексичної компетентності учнів 9 класу, надано характеристику ідіоми як матеріалу для фрормування лексичної компетентності, виокремлено типи труднощів при оволодінні ідіомами, запропоновано підсистему вправ для фрормування англомовної лексичної компетентності на матеріалі ідіом в учнів 9 класу закладів загальної середньої освіти та подано приклади відповідних вправ.

Ключові слова: лексична компетентність, англійська мова, ідіома, ідіоматичність мовлення, зміст лексичної компетентності, середній шкільний вік, заклади загальної середньої освіти.

Подосинникова Анна Игоревна, кандидат педагогических наук, доцент, кафедра германской филологии,

Сумской государственный педагогический университет имени А. С. Макаренко anna_podosinnikova@ukr.net

Ковтун Татьяна Викторовна, студентка,

факультет иностранной и славянской филологии, Сумской государственный педагогический университет имени А. С. Макаренко tanyakovtun25@gmail.com

\section{ФОРМИРОВАНИЕ АНГЛОЯЗЫЧНОЙ ЛЕКСИЧЕСКОЙ КОМПЕТЕНТНОСТИ НА МАТЕРИАЛЕ ИДИОМ У} УЧЕНИКОВ 9 КЛАССА СРЕДНИХ УЧЕБНЫХ ЗАВЕДЕНИЙ

В статье представлены теоретическое обоснование и технология формирования англоязычной лексической компетентности на материале идиом у учащихся 9 класса учреждений общего среднего образования. Очерчены релевантные психолого-возрастные особенности подростков, рассмотрены понятия лексической компетентности, содержание лексической компетентности учащих ся 9 класса, охарактеризованы идиомы как материал для формирования лексической компетентности, выделены типы трудностей при овладении идиомами, предложена подсистема упражнений для формирования англоязычной лексической компетентности на материале идиом у учащихся 9 класса учреждений общего среднего образования и представлены примеры соответствующих упражнений.

Ключевые слова: лексическая компетентность, английский язык, идиома, идиоматичность речи, содержание лексической компетентности, средний школьный возраст, учреждения общего среднего образования.
Podosynnikova, Hanna, Doctor of Pedagogy, Associate Professor, Germanic philology department, A. S. Makarenko Sumy State Pedagogical University anna_podosinnikova@ukr.net

Kovtun, Tetiana Student

Faculty of Foreign and Slavic Philology A. S. Makarenko Sumy State Pedagogical University tanyakovtun25@gmail.com

\section{SECONDARY SCHOOL STUDENTS' ENGLISH LEXICAL} COMPETENCE DEVELOPMENT BASED ON IDIOMS

The article presents the theoretical substantiation and technology of the formation of the English lexical competence using idioms in the 9th form of secondary schools. The related psychological and age peculiarities of teenagers are outlined, the notions of lexical competence as well as the content of lexical competence of the 9th grade students are revealed, the idiom as the material for the formation of the lexical competence is characterized, the types of difficulties in learning idioms are singled out, the subsystem of exercises for the formation of the English lexical competence on the material of idioms in the 9th form of secondary schools is introduced and examples of corresponding exercises are provided.

Keywords: lexical competence, English language, idiom, speech idiomaticity, content of lexical competence, middle school age, general secondary education institutions.

Постановка проблеми. Лексична компетентність $€$ одним із головних складників англомовної комунікативної компетентності учнів закладів загальної середньої освіти (3ЗСО). Навчання англійської мови як засобу міжкультурного спілкування вимагає цілеспрямованої уваги до забезпечення ідіоматичності мовлення тих, хто навчається, щоб вони змогли подивитися на світ очима представника іншої нації, наблизитись до культури носія мови, повною мірою зрозуміти його мовленнєве повідомлення. Ідіоматичні мовленнєві одиниці, які відбивають специфіку вербальної картини світу нації носіїв мови - це той прошарок мови, при вивченні якого виникають значні труднощі. У межах оволодіння англійським ідіоматичними мовленням на середньому та старшому ступенях навчання учням важливо відповідно до вимог і змісту програми опа- 
нувати найчастотніші одиниці фразеологічного рівня - ідіоми, які є важливим компонентом лексичного складу англійської мови. Однак аналіз літератури свідчить, що проблема потенціалу використання ідіом у формуванні англомовної лексичної компетентності (АЛК) учнів середнього ступеня навчання 33СО залишається недостатньо вивченою.

Аналіз останніх досліджень і публікацій. Проблемі формування лексичної компетентності присвячені дослідження К.В. Александрова, Н.І. Гез, І.О. Зимньої, А.А. Міролюбова, С.Ю. Ніколаєвої, Л.С. Панової, Г.В. Рогової, С.В. Смоліної, А.Н. Шамова, С.Ф. Шатілова та інших вітчизняних i зарубіжних учених. Ідіоми як один із важливих компонентів лексичного складу англійської мови розглядалися в працях багатьох дослідників, а саме: М.Ф. Алефіренка, Г.Б. Антрушиної, В.В. Виноградова, О.В. Куніна, Г.І. Подосиннікової, В.Н. Телії, D. Crystal, Ch. Fernando, W. O’Grady, A. Makkai, T. McArthur, R. Moon та ін. Проте досі ще не досліджене питання формування англомовної лексичної компетентності на матеріалі ідіом в учнів 9 класу 33СО.

Метою статті $\epsilon$ охарактеризувати в теоретичному та практичному аспектах розроблену авторами технологію формування англомовної лексичної компетентності на матеріалі ідіом в учнів 9 класу 33СО.

Результати дослідження. Одним із важливих завдань, що постає перед учнями 9 класу $33 С О$ при вивченні англійської мови, є формування АЛК як провідного складника іншомовної комунікативної компетентності. Лексичною компетентністю (ЛК) вважають «здатність людини до коректного оформлення своїх висловлювань і розуміння мовлення інших, яка базується на складній і динамічній взаємодії відповідних навичок, знань і лексичної усвідомленості» (Ніколаєва та ін., 2013, с. 215).

Основу змісту АЛК становлять навички, які розглядають як автоматизовані репродуктивні або рецептивні дії, що забезпечують коректне лексичне оформлення власного мовлення та адекватне сприйняття лексичного оформлення мовлення інших. Лексичні знання - це відображення у свідомості учня результату пізнання лексичної системи іноземної мови у вигляді поняття про цю систему і правил користування нею. До знань, які необхідні для функціонування АЛК, належать: 1) лексична сторона мови; 2) усна і письмова форма слова; 3) відносна цінність слова або його здатність мати синоніми, антоніми, пароніми, омоніми, стилістичну забарвленість; 4) семантика слова; 5) синтаксична і лексична сполучувальна цінність слова; 6) основні поняття, пов'язані зі структурою слова; 7) правила словотвору; 8) схожість та / або розбіжність у лексичних системах рідної та іноземної мов; 9) типи словників (Ніколаєва та ін., 2013 , с. 216). Основним матеріалом для формування лексичних знань є лексичні одиниці (ЛО) - слова, словосполучення, а в окремих випадках, і речення (Панова та ін., 2010, с. 311). Лексична усвідомленість - це здатність учня: 1) розмірковувати над процесами формування своєї АЛК та оволодівати іншомовною лексикою, створюючи систему власних лексичних знань; 2) свідомо реєструвати, розпізнавати і вживати ЛО різних рівнів, їх особливості та закономірності утворення і функціонування; 3) усвідомлювати переваги й недоліки свого типу “мовця” i “учня” відносно оволодіння АЛК; 4) аналізувати лексичну сторону свого мовлення і робити відповідні висновки (Ніколаєва та ін., 2013, с. 217). Лексичні знання, навички та усвідомленість, які є необхідними для здійснення комунікації, створюють лексичну базу для функціонування умінь в усіх видах мовленнєвої діяльності.

Сучасне мовознавство розглядає мову як ієрархічну структуру, що складається з низки рівнів, кожен 3 яких характеризується власним набором мовних знаків. На лексичному рівні функціонують такі одиниці, як слова, словосполучення різного ступеня стійкості, мовленнєві кліше. До змісту так званих «лексичних мінімумів», активного та пасивного, тобто матеріалу для засвоєння учнями 9 класу 33СО, входять одиниці мови різних рівнів - зокрема стійкі словосполучення, які відображують складний феномен ідіоматичності мовлення, що перебуває на перетині полів досліджень психолінгвістики та лінгвістики.

Ідіоматичністю мовлення вважають «психолінгвістичний і лінгвістичний феномен своєрідності світосприймання і вербального менталітету нації, щзо виражається в закріпленні в мовленнєвому узусі певної мови синкретичних мовленнєвих одиниць різного ступеня стійкості, які є специфічними для певної мовленнєвої спільноти в плані структури, семантики й особливостей вживання та викликають труднощуі при доборі повних еквівалентів з інших мов» (Подосиннікова, 2002, с. 1).

Ідіоматичні мовленнсві одиниці - це такі мовленнєві одиниці, які відображують особливості вербального менталітету нації носіїв мови, варіюються за ступенем стійкості та структурної організації, мають синкретичні прагматичні значення і викликають труднощі при доборі повних еквівалентів в інших мовах (Подосиннікова, 2002, с. 4).

Навчаючи англійської мови як засобу міжкультурного спілкування, необхідно цілеспрямовано приділяти увагу забезпеченню ідіоматичності мовлення учнів. Зокрема, важливою групою ідіоматичних мовленнєвих одиниць i, відповідно, вагомим компонентом матеріалу для формування АЛК учнів середнього ступеня 33СО, 
є ідіоми, які часто використовують в автентичних текстах художньої літератури, газет, журналів, радіо і телебачення, а також у повсякденному спілкуванні.

У лінгвістичному понятійному просторі термін «ідіома» може вживатися у вузькому та більш широкому розумінні. У вузькому розумінні, ідіоми, за В. Виноградовим (1977), - це абсолютно неподільні, стійкі поєднання, які функціонують як єдиний блок, ix загальне значення не залежить від значення слівскладнтків. Наведемо приклади: to kick the bucket - загнутися, померти; to rain cats and dogs - лити як з відра (про дош); to be all thumbs - бути невмілим, незграбним; to smell the rat-запідозрювати; green-eyed monster-заздрicmь, ревнощі. У ширшому розумінні, ідіома - це загальний термін для багатьох видів полілексемних одиниць, незалежно від того, чи вони є семантично «непрозорими» (Moon, 1998, с. 4). За О. Куніним (1996), ідіоми - це стійкі поєднання лексем, значення яких є частково або повністю переосмисленим при вагомій ролі конотативного аспекту, його експресивно-оціночних, емотивних, образних та інших компонентів. Зі свого боку, Ч. Фернандо визначає ідіому як морфосинтаксичний феномен, ключовою властивістю якого є асиметрія між значенням та синтаксичною будовою (Fernando \& Flawell, 1981, с. 33).

Проаналізувавши наведені визначення, можна зробити висновок, що ідіоми мають низку характерних ознак, а саме: 1) вони мають високий ступінь стійкості, є сталими у плані значення та синтаксичної будови, можуть бути нероздільними; 2) загальне значення ідіом не залежить від значення їх складників; 3) перестановка компонентів ідіом переважно неможлива, тобто правильно to let one's hair down, a не to let down one's hair; 4) вони не мають у своєму складі додаткових слів, наприклад, не можна сказати to have one's heart in one's brown boots. Крім того, ідіоми можуть містити архаїзми або некротизми, тобто слова, які ніде, крім певної ідіоми, не вживаються, наприклад: to bear the gree - «тримати першість».

Ідіоми, як і інші фразеологічні одиниці, тісно пов’язані з історією, культурою, звичаями і традиціями народу. Вони є носіями лінгвокраїнознавчої інформації, що розглядається як важливий компонент у структурі англомовної комунікативної компетентності. Необхідність використання ідіом у комунікації пояснюється їхньою високою експресивністю, емотивністю й оцінністю, тобто здатністю впливати на емоційну сферу адресата, що є важливим чинником досягнення ефективності стратегічної настанови адресанта (В. В. Виноградов (1977), О. В. Кунін (1996), Г. І. Подосиннікова (2002, 2018), М. Ф. Алефіренко (1987), В. М. Телія (2003), С. В. Брисіна (2003), С. Н. Денисенко (2011), А. М. Мелерович (1997), В. І. Школяренко
(2011, 2019), Ch. Fernando (1981, 1996), R. Moon (1998), A. Makkai (1972), R. Flavell (1981, 1994), S. Granger (2008) та ін.

Об'єктивні причини зумовлюють необхідність добору ідіом для засвоєння учнями 9 класу 33СО, які відповідали би змісту і цілям навчання. До змісту АЛК учнів 9 класу 33СО відносять лексичний матеріал, потрібний для спілкування за визначеною програмою проблематикою, а саме: 1) Personal Information; 2) Natural Resourses; 3) Flora and Fauna; 4) Fashion, Items of Clothing; 5) Internet, Television, Radio; 6) Trends of Youth Culture; 7) Famous Scientists and Inventors; 8) Inventions; 9) Big Cities of Ukraine; 10) Landmarks and Historical Sites; 11) General Characteristics of the English-Speaking Countries; 12) Names of the EnglishSpeaking Countries and their Capitals; 13) Characteristics of Professions; 14) Choice of Profession; 15) Professional Qualities; 16) Inclinations and Abilities. Наприклад, у межах теми Flora and Fauna можна використовувати такі ідіоми: to beat about the bush, last straw, to have a green thumb, the lion's share, bed of roses, to rain cats and dogs, a big fish, a top dog, a shrinking violet.

На відміну від вільних словосполучень, ідіоми, як і інші фразеологічні одиниці, характеризуються ідіоматичністю. Саме через цю ознаку значення фразеологізму як цілого не дорівнює сумі значень його компонентів: навпаки, часто загальне значення абсолютно не корелює зі значеннями слів, які входять до нього, та не має прямого еквівалента при перекладі рідною мовою (наприклад: to show white feather - “бути боягузом”, to eat humble pie - “визнати свою неправоту”), що зумовлює труднощі при формуванні АЛК на матеріалі ідіом. Такий висновок дозволяє спиратися у роботі з ідіомами на загальну типологію труднощів навчання англійських ідоматичних мовленнєвих одиниць (Г.I. Подосиннікова, 2002).

Вважаємо можливим виокремити такі типи труднощів формування АЛК на матеріалі ідіом в учнів 33СО: 1) труднощі в розумінні значення ідіом; 2) труднощі в розумінні семантичних і структурних особливостей ідіом порівняно з еквівалентними конструкціями рідної мови тих, хто навчається; 3) труднощі оцінки комунікативної ситуації (вік, міра знайомства, характер стосунків співрозмовників тощо) з метою остаточного визначення адекватності вживання ідіом в контексті; 4) труднощі у виборі ідіоми як мовленнєвої одиниці, яка є найбільш адекватною в певних комунікативних умовах; 5) труднощі при визначенні місця ідіоми у висловлюванні; 6) планування та реалізація цілісного висловлювання, яке містить ідіому, згідно $з$ комунікативною ситуацією.

Подолання труднощів при формуванні АЛК в учнів 9 класу на матеріалі ідіом може відбуватися 
різними шляхами. Назвемо такі стратегії та прийоми: 1) уточнення відтінку значення ідіоматичної одиниці, вибір еквівалента рідною мовою; 2) групування ідіоматичних одиниць за певними ознаками; 3) оцінювання доцільності вживання ідіоматичних одиниць в певному контексті; 4) вибір ідіоматичної одиниці, яка максимально відповідає певній ситуації спілкування; 5) введення до складу висловлювання ідіоматичної одиниці, що змінює / частково змінює / не змінює загальний зміст висловлювання; 6) комбінування висловлювань та ідіоматичних одиниць (Подосиннікова, 2018, с. 182).

Наведемо приклади відповідних вправ.

Вправа 1. Match the idioms below with their Ukrainian equivalents.

\begin{tabular}{|l|l|}
\hline $\begin{array}{l}\text { not to see the forest for the } \\
\text { trees }\end{array}$ & обіцяти золоті гори \\
\hline $\begin{array}{l}\text { to kill two birds with one } \\
\text { stone }\end{array}$ & називати речі своїми іменами \\
\hline $\begin{array}{l}\text { to make a mountain out of } \\
\text { molehill }\end{array}$ & $\begin{array}{l}\text { вбити двох зайців одним по- } \\
\text { стрілом }\end{array}$ \\
\hline to promise the moon & не бачити за деревами лісу \\
\hline to call a spade a spade & вилити душу \\
\hline tto bare one's heartt & робити з мухи слона \\
\hline
\end{tabular}

Вправа 2. Choose the correct variant of the idioms.

1. I don't know what my family's going to do if our business goes bankrupt. You know, it is in the black/red.

2. I'm very rich! My company sells products in Asia, in the USA... and in Europe! My firm is in the black/red.

3. Don't worry! You've lost your match, but it's not that important. Keep your nose/chin up! You are a very good tennis player! You will win the next match!

4. I can't go out tonight. I have an important test tomorrow. I've got to hit the books/gym.

5. My mother is worrying me. Her health is very bad. She has been feeling over/under the weather all week

Учні 9 класу належать до групи школярів так званого середнього шкільного віку, який відповідає підлітковому періоду життя людини. Знання психолого-вікових особливостей учнів підліткового віку дає змогу учителю обрати такі прийоми, форми та засоби навчання, які найкраще сприятимуть успішному формуванню АЛК учнів.

У підлітковому віці змінюються пізнавальні процеси: дедалі більше розвивається аналітико-синтетична діяльність, намагання зрозуміти виучуване явище, опертися на словесно-логічну пам'ять, звертатися до прийомів опосередкованого, довільного запам'ятовування (Вєтохов, 2004, с. 65-66). Беручи до уваги цю особливість, можна запропонувати учням вправи, спрямовані на осмислення, аналітичне розуміння нової лексики порівняно з одиницями рідної мови з оппертям на засоби наочності, а не просто на механічне її запам'ятовування. Наведемо приклад відповідної вправи.

Вправа 1. Look at the pictures describing the idioms below. Try and guess what they mean.
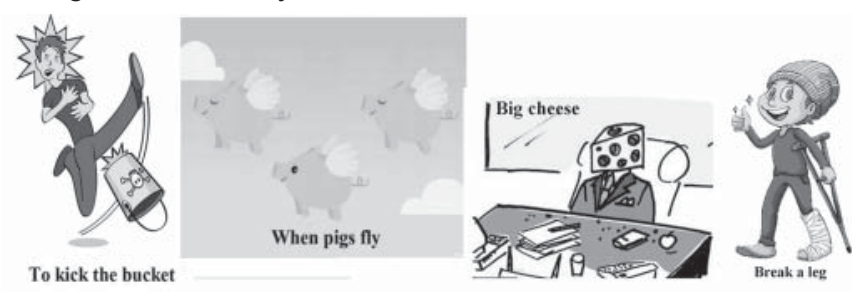

На цьому ступені навчання учні набувають навичок самостійного розуміння значної кількості слів та словосполучень, що містяться в текстах для читання, 3 опертям на розвинуте аналітичне мислення, уяву, пам'ять. Учитель має показати учням, як можна самостійно здогадатись про значення незнайомої лексики 3 опертям на контекст, словотворчі елементи, інтернаціональні слова, засвоєні раніше співзначення багатозначних слів (Панова та ін., 2010, с. 228). Наведемо приклад відповідної вправи.

Вправа 1. Here is a story about a successful friend who has had a fantastic career. Try reading the story one time to understand the gist without using the idiom definitions. On your second reading, use the definitions to help you understand the text while learning new idioms.

My successful friend (by Kenneth Beare)
Let me tell you a little bit about my friend Doug. It was clear
from the very beginning that he was going places. He did very
well in school, and everyone knew he was a smart cookie. Not
only were his grades good, but he was also an outstanding
athlete, as well as keeping his nose clean. Some accused him
of being squeaky clean, but that didn't bother him. He wasn't
going to let anyone rain on his parade!
After he graduated from college, he decided to go to New York.
Back in those days, New York was a hotbed of innovation.
Doug was a product design specialist and had some great
designs on tap. Unfortunately, he didn't immediately succeed.
In any case, it soon became clear to him that he needed to
make some brownie points with his director. He decided he
would volunteer to create the presentation for a new product
at the company's yearly dog and pony show.
The boss wasn't so sure, but the decision about who would
make the presentation wasn't carved in stone. In the end,
the manager decided that Doug would do a good job. Doug
gladly accepted the challenge and decided to make quite an
impression. He felt that giving a great presentation would
improve his standing in the company.
The day of the presentation arrived, and, no surprise, Doug
did an outstanding job. His presentation was informative,
and he didn't blow any smoke. Where there were problems, he
pointed them out and made suggestions as to how to improve the
situation. Long story short, because of his excellentpresentation
the directorrealized thathewas the genuine article. Within three
years, he had sealed the deal on the development of two of his
best ideas. As they say, the rest is history.
The source: https://www.thoughtco.com/my-successful-friend-1211229
a


Щодо особливостей мотиваційної сфери старших підлітків, то більшості з них властива індивідуалістична акцентуація особистості, тобто спрямованість особистісної активності на задоволення власних потреб, самоствердження (Фельдштейн, 2008, с. 17). Отже, беручи до уваги цю особливість, можна запропонувати учням вправу, де можлива реалізація їхніх думок та вираження своєї особистості. Наведемо відповідний приклад.

Вправа 1. Each and every one of us is a unique personality. All of us have different hobbies, interests, and talents. Make up a story about yourself, but also try to confuse your classmates by telling them some fake facts about you. Their task is to guess which facts aren't true. Try and use the expressions given below.

\begin{tabular}{c} 
Lone wolf $\begin{array}{c}\text { Early bird } \\
\text { Pig-headed Head in the clouds }\end{array}$ \\
\hline
\end{tabular}

Ураховуючи викладене вище, пропонуємо комплекс вправ для формування АЛК на матеріалі ідіом в учнів 9 класу 33СО. Структура комплексу вправ складається з трьох груп вправ, які корелюють 3 відповідними етапами формування репродуктивної лексичної навички та розглянутими вище труднощами засвоєння ідіом. Запропонований комплекс вправ візуалізовано в на Рис. 1.

\begin{tabular}{|c|c|c|}
\hline \multicolumn{3}{|c|}{$\begin{array}{c}\text { Комплекс вправ для формування АЛК на матеріалі } \\
\text { ідіом в учнів } 9 \text { класу ЗЗСО. }\end{array}$} \\
\hline & & 1 \\
\hline $\begin{array}{c}\text { Група вправ, } \\
\text { спрямована } \\
\text { на ознайом- } \\
\text { лення учнів } 3 \\
\text { новими ЛО }\end{array}$ & $\begin{array}{c}\text { Група вправ, } \\
\text { спрямована на } \\
\text { автоматизацію } \\
\text { дій учнів } 3 \text { нови- } \\
\text { ми ЛО на рівні } \\
\text { словоформи, сло- } \\
\text { восполучення та } \\
\text { фрази/речення }\end{array}$ & \begin{tabular}{|c|} 
Група вправ, \\
спрямована \\
на автома- \\
тизацію дій \\
учнів на рів- \\
ні надфразо- \\
вої сдності
\end{tabular} \\
\hline $\begin{array}{c}\text { Рецептивні } \\
\text { умовно-ко- } \\
\text { мунікативні, } \\
\text { некомуніка- } \\
\text { тивні, ігрові }\end{array}$ & $\begin{array}{c}\text { Репродуктивні, } \\
\text { продуктивні } \\
\text { умовнокомуніка- } \\
\text { тивні вправи }\end{array}$ & $\begin{array}{c}\text { Продуктивні } \\
\text { умовно-ко- } \\
\text { мунікативні, } \\
\text { комуніка- } \\
\text { тивні вправи }\end{array}$ \\
\hline
\end{tabular}

Рис. 1. Комплекс вправ для формування АЛК на матеріалі ідіом в учнів 9 класу

Розглянемо групи вправ докладніше. Група вправ, спрямована на ознайомлення $з$ новими ЛО, починається з презентації у контексті та семантизаu̧iї, тобто розкриття значення, нових ЛО. Вибір способу семантизації ідіоми залежить від ряду факторів, насамперед від іiї лінгвістичних особливостей: форми, значення, сполучуваності, ступеня та характеру збігу / розбіжності з ЛО рідної мови, належність ЛО до пасивного чи активного мінімуму (Ніколаєва та ін., 2013, с. 225). Вправи цієї групи забезпечують подолання труднощів розуміння значення та семантичних і структурних особливостей ідіоматичної ЛО порівня- но з еквівалентними конструкціями рідної мови. До цієї групи належать рецептивні умовно-комунікативні та некомунікативні ігрові вправи (з мінімальною вербальною реакцією). Основним режимом роботи $є$ фронтальний. Наведемо приклади вправ.

Вправа 1. Look at the pictures describing people's personalities. Match the pictures with a suitable meaning and guess what they mean.
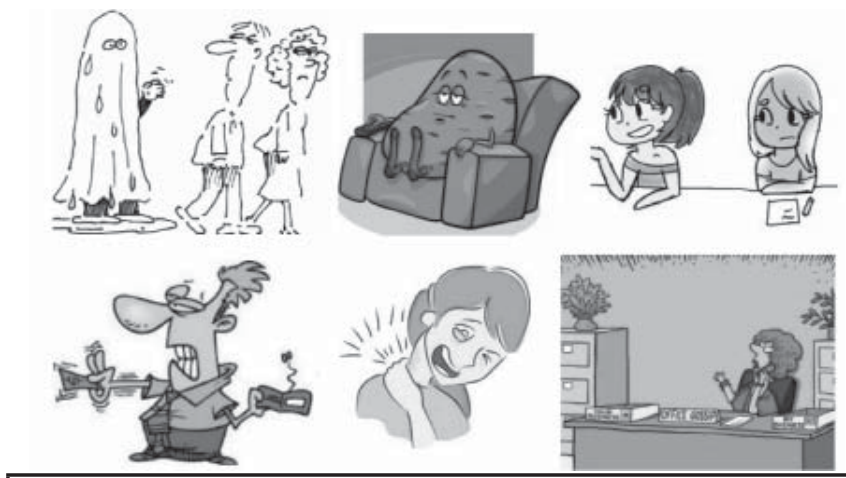

To be a wallflower to be a pain in the neck to be a wet blanket

\section{to be a cheapskate to be a couch potato to be a busybody}

Вправа 2. Listen and read about my friends' negative traits of character. Try to translate the idioms in bold type.

\begin{tabular}{|l|l|}
\hline & $\begin{array}{l}\text { My friend Sam likes sitting in front } \\
\text { of a TV doing nothing. That's why } \\
\text { people often call him a couch potato. } \\
\text { He's a cheapskate, because he } \\
\text { doesn't like spending much money. }\end{array}$ \\
\hline $\begin{array}{l}\text { Simon is a wallflower, so he doesn't } \\
\text { enjoy going to parties because } \\
\text { he finds it difficult to talk to new } \\
\text { people. Quite often he can be a wet } \\
\text { blanket and ruin other people's fun. }\end{array}$ & $\begin{array}{l}\text { Rachel is a true picture of a } \\
\text { busybody. She always knows } \\
\text { everything about everyone, even } \\
\text { if it's not her business. And pretty } \\
\text { often she becomes so annoying like } \\
\text { a pain in the neck. }\end{array}$ \\
\hline
\end{tabular}

Вправа 3. Let's play a game. I will be telling you something about these kinds of people and you will clap when you hear a lie.

- Lazy people are often called wet blankets.

- When you don't want your secret to come out, don't tell it to a busybody.

- When somebody cries very often, they are called a pain in the neck.

- People who spoil your mood are called wet blankets.

- A girl or a boy who is always quiet is called cheapskate.

- Couch potatoes love watching TV.

- Wallflowers usually don't go out much. 
Наступною є група вправ, спрямована на автоматизацію дій учнів з новими ЛО на рівні словоформи, вільного словосполучення та фрази/речення. Тут необхідно встановити міцні зв'язки між ЛО та їх значенням і сформувати автоматизовані, стійкі, а також гнучкі навички застосування ідіоми. На цьому етапі слід забезпечити достатню кількість і різноманітність вправ на закріплення первинних навичок вживання ЛО в заданому комунікативному контексті. Розглядана група вправ спрямована на подолання труднощів оцінювання комунікативної ситуації з метою остаточного визначення адекватності вживання ідіоматичних одиниць в контексті та труднощів при визначенні їх місця у висловлюванні. У навчальній діяльності домінують (рецептивно-)репродуктивні та продуктивні умовно-комунікативні вправи, у яких учень сприймає зразок мовлення (3М) і в усній чи письмовій формі виконує із ЗМ певні дії згідно зі створеною учителем ситуацією мовлення: 1) імітація; 2) лаконічні відповіді на альтернативні запитання вчителя; 3) підстановка; 4) завершення, доповнення, розширення; 5) відповіді на інші типи питань; 6) самостійне вживання у фразі/ реченні (Ніколаєва та ін., 2013, с. 229). Характерні режими роботи - фронтальний, індивідуальний, парний. Наведемо приклади таких вправ.

Вправа 1. Here are some interesting expressions characterizing people. Match them with a suitable sentence and then check your answer with the key. Can you apply these words to yourself or people you know?

\begin{tabular}{|l|l|}
\hline a. to be a cheapskate & 1 . He's a real nuisance. I can't stand him. \\
\hline $\begin{array}{l}\text { b. to be a pain in the } \\
\text { neck }\end{array}$ & $\begin{array}{l}\text { 2. My dad's such a stingy person that } \\
\text { he cuts his hair himself. }\end{array}$ \\
\hline $\begin{array}{l}\text { c. to be a wet } \\
\text { blanket }\end{array}$ & $\begin{array}{l}\text { 3. Eventually, he'll stop being so shy } \\
\text { and asks her to go out. }\end{array}$ \\
\hline d. to be a wallflower & $\begin{array}{l}\text { 4. Danny is so pessimistic lately, I } \\
\text { wonder what happened. }\end{array}$ \\
\hline e. to be a busybody & $\begin{array}{l}\text { 5. I wish her TV stopped working. She } \\
\text { doesn't go outside at all! }\end{array}$ \\
\hline $\begin{array}{l}\text { f. to be a couch } \\
\text { potato }\end{array}$ & $\begin{array}{l}\text { 6. She is telling everyone that my par- } \\
\text { ents are getting divorced. }\end{array}$ \\
\hline
\end{tabular}

Вправа 2. Find synonyms and antonyms to the given expressions. Group them into three columns: Idiom - synonym - antonym. Remember, there may be more than one synonym and antonym to each expression.

\begin{tabular}{|cc|}
\hline $\begin{array}{c}\text { Cheapskate } \\
\text { Pain in the neck }\end{array}$ & $\begin{array}{c}\text { Busybody Wet blanket } \\
\text { Couch potato Wallflower }\end{array}$ \\
\hline
\end{tabular}

Shy optimistic generous annoying active talkative stingy quiet lazy pleasant outgoing negative modest pessimistic greedy sociable idle reserved agreeable productive

\begin{tabular}{|c|c|c|}
\hline Idiom & Synonym & Antonym \\
\hline & & \\
\hline & & \\
\hline & & \\
\hline
\end{tabular}

Вправа 3. Read these sentences and fill in the gaps with the idioms from the box below.

\begin{tabular}{|cc|}
\hline \multicolumn{2}{|c|}{ The tip of the iceberg } \\
To be in deep water & To beat around the bush \\
Down to earth & A drop in the ocean \\
\hline
\end{tabular}

1. Life isn't You have to work hard to achieve something!

2. The news reporter said that we are because of the rise of carbon dioxide in the atmosphere. It's too late for planting trees!

3. One person is a But if we all start recycling, we can save plants, animals and ourselves!

4. The government is just Global warming is an urgent problem and they have to take action!

5. Therise in temperature is only Next up is the melting of glaciers, sea-level rise, forest fires and so on.

6. At first I didn't want to talk to him because he seemed so arrogant, but then I got to know him better, and he is actually

Вправа 4. In turns ask your partner about his/her classmates using the vocabulary. Answer the questions giving the opposite characteristic. Example: Is Max a pain in the neck? - No, he's quite pleasant
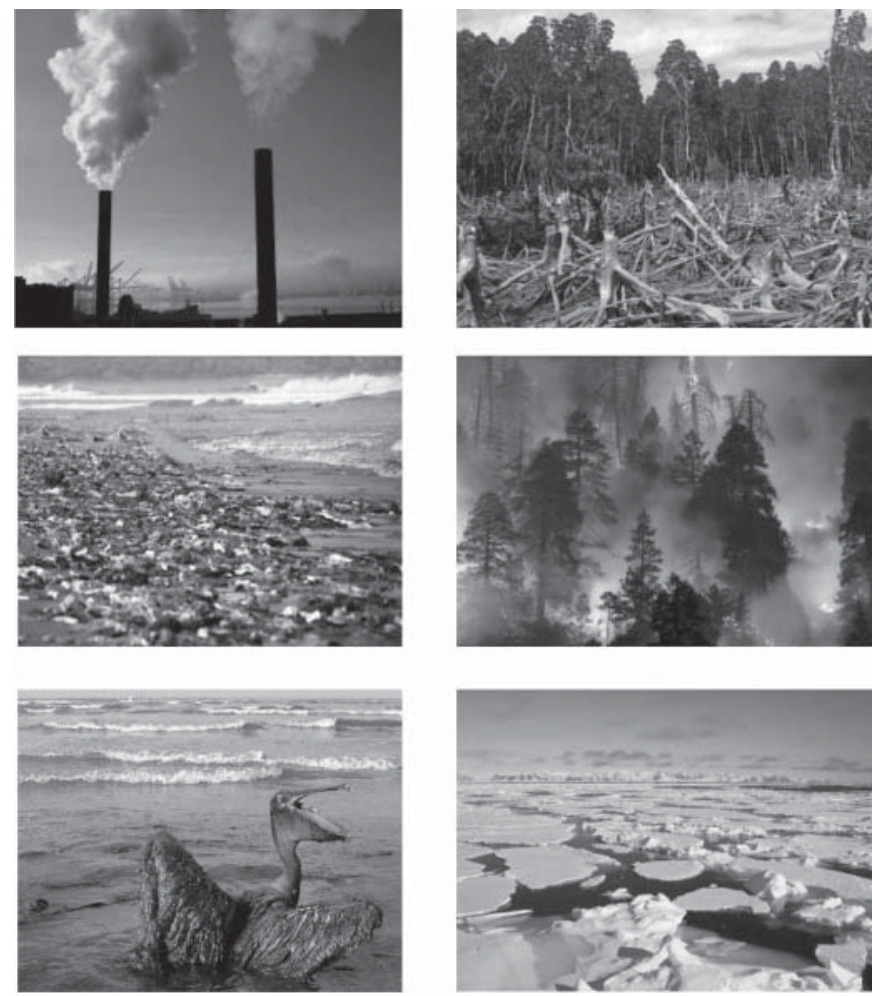

Останньою є група вправ, спрямована на автоматизацію дій учнів 3 новими ЛО на рівні надфразної єдності, за допомогою цих вправ учень здійснює відтворення ЛО на продуктивному рівні. Учитель створює умови для спілкування в усній i 
письмовій формі з використанням нових ЛО, а учні вживають нову лексику в мовленні відповідності до пропонованої комунікативної ситуації спілкування (Смоліна, 2010, с. 20). Метою цієї групи вправ є подальше формування автоматизованості і гнучкості навички. Вправи цієї групи спрямовані на подолання таких труднощів як: 1) вибір ідіоматичних одиниць як мовленнєвої одиниці, яка є найбільш адекватною в певних комунікативних умовах; 2) планування та реалізація цілісного висловлювання згідно 3 комунікативною ситуацією. Характерні такі типи вправ: умовно-комунікативні, комунікативні та репродуктивні. Режими роботи - індивідуальний, парний, мікрогруповий. Наведемо приклади відповідних вправ.

Bправа 1. Do you know what's happening in the world today? With the environment in particular? There are lots of ecological problems nowadays. Work in pairs. Each pair will have one picture. Your task is to tell the class something about this problem in turns. Use the active vocabulary.

Вправа 2. Can you remember a character from a film, a cartoon or a book that fits the description of one of these idioms? Speak about that character. Use the scheme below:

The name of the character

Where are they from

Your personal opinion on the character

Their personal traits

Вправа 3. Imagine that genie gave you one wish. With this wish you can solve one environmental problem forever. Tell us about that problem and the reasons why you chose it. Use the active vocabulary.

Результати дослідження. Отже, ідіоми є важливим компонентом лексичного складника англійської мови, формування навичок уживання ідіом $€$ аспектом опанування ідіоматичного мовлення. Використання науково обгрунтованої підсистеми вправ підвищуе ефективність формування АЛК в учнів 9 класу і дає їм змогу подивитися на світ очима представника іншої нації, наблизитися до культури носія мови.

Перспективи подальших розвідок убачаємо у створенні системи вправ для формування АЛК на матеріалі ідіом для середнього та старшого ступенів навчання у $33 \mathrm{CO}$ з урахуванням труднощів, зумовлених віком учнів, а також системи вправ для формування АЛК на матеріалі фразеологічних одиниць для середнього та / або старшого ступенів навчання у $33 \mathrm{CO}$.

\section{СПИСОК ПОСИЛАНЬ}

Вєтохов, О. М. Основні етапи, напрями і способи подання психологічної допомоги учням (на матеріалі навчання іноземної мови) (Організац. навч. проц.). Педагогіка і психологія. 2004. № 2. С. 62-70.

Виноградов В. В. Лексикология и лексикография : избр. тр. / отв. ред. В. Г. Костомаров. Москва, 1977. 312 с.

Крутецкий В. А. Психология: учебник для учащихся пед. училищ. Москва : Просвещение, 1980. 352 с.

Кунин А. В. Курс фрразеологии современного английского языка : учеб. для ин-тов и фрак. иностр. яз. Изд. 2-е, перераб. Москва, 1996. 381 с.

Методика навчання іноземних мов і культур: теорія і практика : підручник для студ. класичних, педагогічних і лінгвістичних університетів / Бігич О. Б., Бориско Н. Ф., Борецька Г. Е. та ін. / за загальн. ред. С. Ю. Ніколаєвої. Київ, 2013. 590 с.

Методика навчання іноземних мов у загальноосвітніх навчальних закладах: підручник/Л. С. Панова та ін. Київ, 2010. 328 с.

Подосиннікова Г. І. Методична типологія труднощів навчання ідіоматичного розмовного мовлення майбутніх учителів англійської мови. Педагогічні науки: теорія, історія, інноваційні технології. 2018. № 4. С. 172-185.

Подосиннікова Г. І. Навчання студентів-фрілологів ідіоматичних предикативних конструкцій англійського розмовного мовлення на матеріалі автентичних художніх текстів : автореф. дис. на здобуття наук. ступеня канд. пед. наук: 13.00.02. Київ, 2002. 13 с.

Смоліна С. В. Методика формування іншомовної лексичної компетентності. Іноземні мови. 2010. № 4. С. 16-23

Фельдштейн Д. И. Трудный подросток. Изд. 2-е. Москва, 2008. 208 с Fernando Ch., Flavell R. Ch. Fernando On Idiom: Critical Views And Perspectives : Exeter Linguistic Studies. 1981. Vol. 36, № 5. P. 18-48.

Moon R. Fixed expressions and idioms in English: a corpus-based approach. Oxford, 1998. 340 p.

\section{REFERENCES}

Vietokhov, O. M. Osnovni etapy,napriamy i sposoby podannia psykholohichnoi dopomohy uchniam (na materiali navchannia inozemnoi movy) (Orhanizats. navch. prots.). Pedahohika i psykholohiia. 2004. №2. S. 62-70.

Vynohradov V. V. Leksykolohyia y leksykohrafyia : yzbr. tr. / otv. red. V.H. Kostomarov. Moskva, 1977. 312 s.

Krutetskyi V. A. Psykholohyia: Uchebnyk dlia uchashchykhsia ped. uchylyshch. Moskva : Prosveshchenye, 1980. 352 s.

Kunin A. V. Kurs frazeolohyy sovremennoho anhlyiskoho yazyka : ucheb. dlia yn-tov y fak. ynostr. yaz. Yzd. 2-e, pererab. Moskva, 1996. $381 \mathrm{~s}$.

Metodyka navchannia inozemnykh mov i kultur: teoriia i praktyka : pidruchnyk dlia stud. klasychnykh, pedahohichnykh i linhvistychnykh universytetiv / Bihych O. B., Borysko N. F., Boretska H. E. ta in. / za zahaln. red. S. Yu. Nikolaievoi. Kyiv, 2013. $590 \mathrm{~s}$.

Metodyka navchannia inozemnykh mov u zahalnoosvitnikh navchalnykh zakladakh: pidruchnyk / L. S. Panova ta in. Kyiv, 2010. 328 s.

Podosynnikova H. I. Metodychna typolohiia trudnoshchiv navchannia idiomatychnoho rozmovnoho movlennia maibutnikh uchyteliv anhliiskoi movy. Pedahohichni nauky: teoriia, istoriia, innovatsiini tekhnolohii. 2018. №4. S. 172-185.

Podosynnikova H. I. Navchannia studentiv-filolohiv idiomatychnykh predykatyvnykh konstruktsii anhliiskoho rozmovnoho movlennia na materiali avtentychnykh khudozhnikh tekstiv : avtoref. dys. na zdobuttia nauk. stupenia kand. ped. nauk : 13.00.02. Kyiv, 2002. $13 \mathrm{~s}$.

Smolina S. V. Metodyka formuvannia inshomovnoi leksychnoi kompetentnosti. Inozemni movy. 2010. №4. S. 16-23

Feldshtein D. Y. Trudnyi podrostok. Yzd. 2-e. Moskva, 2008. 208 s.

Fernando Ch., Flavell R. Ch. Fernando On Idiom: Critical Views And Perspectives : Exeter Linguistic Studies. 1981. Vol. 36, № 5. P. 18-48.

Moon R. Fixed expressions and idioms in English: a corpus-based approach. Oxford, 1998. 340 p.

Отримано 17.08.20 